\title{
Physico-Chemical Characterization and Antioxidant Activity of Miconia Ciliata (rich.) Dc Infrutescences in Two Maturation Stages
}

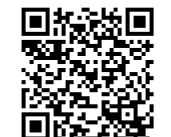

Patrícia da Silva Machado*, Ana Beatriz Silva Araújo, Andreza Stephanie de Souza Pereira, Elisângela Elena
Nunes Carvalho and Eduardo Valério de Barros Vilas Boas

Department of Food Science, Federal University of Lavras, Brazil

Submission: January 25, 2019; Published: Febrauary 19, 2019

*Corresponding author: Patrícia da Silva Machado, Federal University of Lavras, Department of Food Science, University Campus, Lavras- MG, Brazil

Abstract

Miconia is the biggest genus of Melastomatacea Juss, a family with pantropical distribution. The present study aimed to conduct the physicochemical characterization and evaluate the antioxidant capacity of Miconia ciliata infrutescences. Analyses of $\mathrm{pH}$, titratable acidity, total sugars, soluble pectin, total phenol, vitamin C, monomeric anthocyanins, antioxidant activity (DPPH) and color (L, C, oh) were conducted. The pH increased as acidity decreased, while soluble solids, total sugars and soluble pectin increased and total phenol, vitamin C, antioxidant activity and clarity increased as maturation advanced. Monomeric anthocyanins were only detected in mature infrutescences, while the green ones presented more vivid color. The hue angle changed from green to purple from the green-mature to mature infrutescences, respectively. Miconia ciliata infrutescences have significant amounts of total phenols, are source of vitamin C and present sensory and functional appeal.

Keywords: Vitamin C; Total phenol; Functional; Melastomataceae

\section{Introduction}

Miconia is the biggest genus of Melastomatacea Juss, a family with pantropical distribution, however most of species is found in the Neotropical region [1,2]. It is composed by approximately 150 genera and 4500 species, with 66 genera and 1370 occurring in Brazil, representing the sixth most diverse family in the country [3]. Miconia species are generally described by collectors like shrubs or small trees (4-5m). Many species present a great variability of height and may attain from 10 to $30 \mathrm{~m}$ [4]. The fruit is a berry regularly finalized by the lacinium of cup or thalamus of hypantoand species present deciduous chalice [5]. The family lacks data on the industrial, food and/or medicinal importance, since only few compounds were isolated [6]. The study of little known species may reveal information that support the generation of income and employments for local communities due to the correct exploration of biodiversity, as well as help on reducing deforestation [7] and provide information for more specific studies in several areas like food and pharmaceutical industries. Then, the physical and chemical characterization of plants is important for the evaluation of quality, technological classification, provision of secure information to determine the nutritional value, yield, processing operations to be used and the product lifespan [8].
In the state of Pará the consumption of Miconia ciliata (Rich.) by children that walk along streams is common. Fruits are generally known as "uvinha", "chumbinho" and "canela-de-veado". The lack of scientific data on physico-chemical parameters and antioxidant potential of infrutescences of Miconia ciliate make the studies greatly important given the relevance of such species for the Brazilian flora and communities. In this sense, the present study aimed to characterize physico-chemical traits and evaluate the antioxidant potential of Miconia ciliate in two maturation stages. Green-mature and mature fruits were collected in Vila do Apeú (11'00.1”S 475ㅗ'50.9”W), municipality of Castanhal, state of Pará, Brazil, and transported to the Laboratory of Postharvest of Fruits and Vegetables of Federal University of Lavras, where $\mathrm{pH}$, titratable acidity, soluble solids, total sugars, soluble pectin, color ( $\mathrm{L}, \mathrm{C}$, and $\mathrm{h}$ ), total phenols, vitamin $\mathrm{C}$, monomeric anthocyanin and antioxidant activity were evaluated using the method DPPH.

The analyses are described as follows: pH was determined using a pHmeter Tec - 3MP (TECNAL) according to the technique of AOAC [9]. The determination of titratable acidity was conducted according to Instituto Adolfo Lutz [10]. Results were expressed in percentage of citric acid. The digital portable Refractometer PAL-1 (ATAGO) was used to determine the soluble 
solids. Results were expressed in percentage of soluble solids [9]. Total sugars were determined by the method of Antrona [11]. Results were expressed in mg.100g-1. The extraction of pectin soluble substances was conducted according to the technique described by McCready \& McComb [12] and the determination was made by Bitter \& Muir [13] method. Results were expressed in mg of galacturonic acid. $100 \mathrm{~g}-1$ of fruit. The total phenols were made by Folin-Ciocalteau method [14]. Results were expressed in mg of galic acid equivalent (AGE).100g-1 of fruit. The content of ascorbic acid was determined by Strohecker \& Henning [15] method. Results were expressed in mg of ascorbic acid.100g-1 of fruit. The analysis of anthocyanins was conducted according to the method of differential pH proposed by Giusti \& Wrolstad [16]. Results were expressed in mg.100g-1 of sample. The determination of antioxidant activity was conducted by means of the method of sequestration of radicals DPPH by antioxidants, according to Brand-Williams, Cuvelier \& Berset [17], adapted by Rufino et al. [18]. Results were expressed in \% of sequestration of free radical (\% FRS). The coloration was performed using a Minolta colorimeter CR-400 in the model CIE L*a*b*, as well as illuminant D65. The variables $\mathrm{L}^{*}$, angle hue $\left(\mathrm{h}^{\circ}\right)$ and chroma $\left(\mathrm{C}^{*}\right)$ were considered. All analyses were conducted in triplicate and expressed as means \pm standard deviation by means of the software MS Excel (Microsoft Office 2010 Professional).
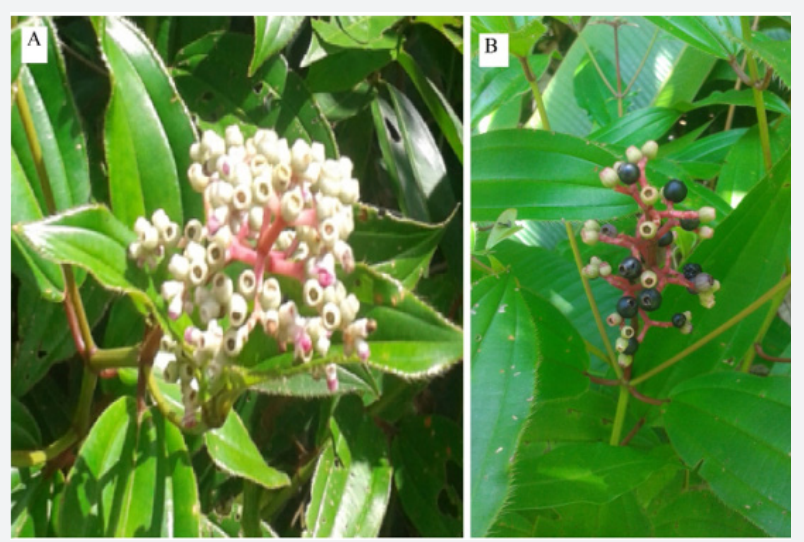

Figure 1: Green-mature $(A)$ and ripe infrutescences $(B)$ of Miconia ciliata.

The pH (Table 1) of ripe (Figure 1) infrutescences was higher, while acidity was higher in green infrutescences. Soluble solids, total sugars and soluble pectin were higher in ripe infrutescences. Phenolic compound content and antioxidant activities determined by DPPH were higher in green-mature infrutescences. Table 1 presents the reduction of vitamin $\mathrm{C}$ content as maturing advances. In relation to anthocyanins, they were found only in ripe infrutescences. Regarding the color, the green-mature infrutescences of Miconia ciliata were clearer and presented more vivid color, while in relation to the hue angle, the green-mature was green and the ripe was purple.

In general during maturing of fruits there is an increase of $\mathrm{pH}$ and decrease of total acidity resultant from the reduction of organic acids [19]. According to the classification of Franco and Landgraf [20], foods with $\mathrm{pH}$ equal or inferior to 4.0 may be classified as acid and very acid, respectively, in this sense greenmature and mature infrutescences of Miconia ciliata may be considered very acid and acid, respectively. The sugar content, besides determining the degree of sweetness, also provides information on the technological potential, microbiological susceptibility and together with acidity is correlated with the parameter of flavor quality. The sweetness of fruits depends on the soluble solids, since most of them are sugars [21]. In relation to pectin, one of the main components of primary cell wall, it is frequently described as a highly complex polysaccharide rich in galacturonic acid [22]. It represents about one third of the cell wall structure [23] and its solubilization is related to the fruit softening.

Table 1: Mean values of $\mathrm{pH}$, titratable acidity, soluble solids, total sugars, soluble pectin, vitamin C, monomeric anthocianin, DPPH and color of infrutescences of Miconia ciliata.

\begin{tabular}{|c|c|c|}
\hline & Green-Mature & Mature \\
\hline $\mathrm{pH}$ & $3.68 \pm 0.02$ & $4.05 \pm 0.11$ \\
\hline Titratable acidity (\%) & $0.85 \pm 0.05$ & $0.42 \pm 0.02$ \\
\hline Soluble solids (\%) & $3.0 \pm 0.0$ & $6.67 \pm 0.0$ \\
\hline Total sugars(mg 100-1 g) & $808.28 \pm 35.86$ & $3089.76 \pm 39.05$ \\
\hline Soluble pectin (mg 100-1 g) & $37.62 \pm 2.99$ & $93.75 \pm 0.93$ \\
\hline Total phenols (mg 100-1 g) & $562.87 \pm 31.94$ & $305.85 \pm 3.3$ \\
\hline Vitamin C (mg 100- 1 g) & $78.15 \pm 0.65$ & $33.20 \pm 0.83$ \\
\hline $\begin{array}{c}\text { Monomeric anthocyanins } \\
\text { (mg 100-1 g) }\end{array}$ & - & $86.82 \pm 0.28$ \\
\hline DPPH- \% FRS & $93.06 \pm 2.4$ & $40.95 \pm 1.17$ \\
\hline L & $33.17 \pm 0.31$ & $19.54 \pm 0.63$ \\
\hline C & $21.54 \pm 0.5$ & $1.84 \pm 0.06$ \\
\hline oh & $78.57 \pm 0.07$ & $294.23 \pm 2.74$ \\
\hline
\end{tabular}

Values presented represent mean \pm standard deviation of triplicates.

The phenolic compound content reduced as maturing advanced. Some authors associated the reduction of antioxidant capacity along maturing with the decrease of phenolic compounds and other bioactive compounds [24,25]. Neves et al. [26] also observed the reduction of vitamin $\mathrm{C}$ along maturing in 8 different Amazon fruits. Considering the daily need of vitamin C intake for women (75mg) and children (45mg) [26], $100 \mathrm{~g}$ of Miconia ciliata infrutescences can attend this need, thus demonstrating that they represent sources of vitamin C. The presence of anthocyanins only in ripe infrutescences may be explained by its synthesis and degradation of chlorophylls that occur parallel to the development and maturing of fruits $[27,28]$. Miconia ciliata infrutescences have sensory and functional appeal, with significant amounts of total phenols and vitamin C. However the study of anti-nutritional factors is recommended since it is a non-conventional food.

\section{Acknowledgement}

The authors would like to thank the Coordination of Improvement of Higher Education Personnel (Coordenação de Aperfeiçoamento de Pessoal de Nível Superior - CAPES), the National Council for Scientific and Technological Development 
(Conselho Nacional de Desenvolvimento Científico e Tecnológico - CNPq) and Foundation for Research Support of the State of Minas Gerais (FAPEMIG) for their fundamental financial support for this work.

\section{References}

1. Renner SS (1993) Phylogeny and classification of the Melastomataceae and Memecylaceae. Nordic Journal of Botany 13(5): 519-540.

2. Romero R, Martins AB (2002) Melastomataceae do Parque Nacional da Serra da Canastra, Minas Gerais, Brasil. Revista Brasileira de Botânica 25(1): 19-24.

3. Baumgratz JFA, Caddah MK, Chiavegatto B, Goldenberg R, Guimarães PJF, et al. (2015) Melastomataceae In Lista de Espécies da Flora do Brasil. Jardim Botânico do Rio de Janeiro.

4. Chagas ECO (2012) O Gênero Miconia Ruiz \& Pav. (Melastomataceae) na Floresta Atlântica Do Nordeste Oriental. Dissertação (Mestrado em Biologia Vegetal) -Universidade Federal de Pernambuco, Recife-PE, p. 125.

5. Goldenberg R, Penneys DS, Almeda F, Judd WS, Michelangeli FA (2008) Phylogeny of Miconia (Melastomataceae): patterns of stamen diversification in a megadiverse neotropical genus. International Journal of Plant Sciences 169(7): 963-979.

6. Cunha WR, Silva MLA, Turatti ICC, Ferreira DS, Betarello HL (2003) Avaliação da atividade analgésica de Miconialigustroides (Melastomataceae) utilizando o teste de contorção abdominal em camundongos. Revista Brasileira de Farmácia, 84: 47-49.

7. Homma AKO (2005) Biopirataria na Amazônia: como reduzir os riscos? Amazônica: Ciência \& Desenvolvimento 1(1).

8. Augusta IM, Resende JM, Borges SV, Maia MCA, Couto MAPG (2010) Caracterização física e química da casca e polpa e jambo vermelho (Syzygiummalaccensis (L.) Merryl\& Perry). Ciênc Tecnol Aliment 30(4): 928-932.

9. Association of Official Analytical Chemists (2002) Official methods of analysis of analysis of the Association of Official Analytical Chemistry. (1 $7^{\text {th }}$ edn). Washinton, USA, p. 1115 .

10. Instituto Adolfo Lutz (2008) Normas analíticas do Instituto Adolfo Lutz: métodos químicos e físicos para análise de alimentos. ( $4^{\text {th }}$ edn). São Paulo, Brazil, p. 371.

11. Dische Z (1962) General color reactions. In: Whistler RL, Wolfran ML(Eds.), Carboydrates chemistry 1: 477-512.

12. McCready PM, McComb EA (1952) Extraction and determination of total pectic material. Analytical Chemistry 24(12): 1586-1588.

13. Bitter T, Muir HM (1962) A modified uronic acid carbazole reaction. Anal Biochem 4: 330-334.

14. Waterhouse AL (2002) Polyphenolics: determination of total pheno-

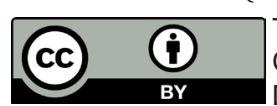

This work is licensed under Creative

Commons Attribution 4.0 License

DOI: 10.19080/CTBEB.2019.18.555987 lics. In: Wrolstad RE (Ed.), Current protocols in food analytical chemistry. J Wiley, New York, USA, pp. 1073-1080.

15. Strohecker R, Henning HM (1967) Analisis de vitaminas: métodos comprobados. Madrid, Paz Montalvo, p. 428.

16. Giusti MM, Wrolstad RE (2001) Anthocyanins: characterization and measurement with uv-visible spectroscopy. protocols in food analytical chemistry (1): 1-13.

17. Brand-Wiliams W, Cuvelier ME, Berset C (1995) Use of a free radical method to evaluate antioxidant activity. Food Science and Technology 28(1): $25-30$

18. Rufino MSM, Alves RE, Brito ES, Morais SM, Sampaio CG, et al. (2007) Metodologia científica: determinação da atividade antioxidante total em frutas pela captura do radical livre DPPH. Fortaleza: Embrapa p. 4.

19. Pinto PM, Jacomino AP, Silva SR, Andrade CAW (2013) Ponto de colheita e maturação de frutos de camucamu colhidos em diferentes estádios. Pesquisa Agropecuária Brasileira 48(6): 605-612.

20. Franco BDGM, Landgraf M (2005) Microbiologia dos alimentos. São Paulo, Atheneu, p. 196.

21. Cao F, Guan C, Dai H, Li X, Zhang Z (2015) Soluble solids content is positively correlated with phosphorus content in ripening strawberry fruits. Scientia Horticulturae 195: 183-187.

22. Caffall KH, Mohnen D (2009) The structure, function and biosynthesis of plant cell wall pectic polysaccharides. Carbohydrate Research 344(14): 1879-1900.

23. Ridley BL, O'neil MA, Mohnen D (2001) Pectins: structure, biosynthesis and oligogalacturonide-related signaling. Phytochemistry 57(6): 929967.

24. Benchikh Y, Louaileche H, George B, Merlin A (2014) Changes in bioactive phytochemical content and in vitro antioxidant activity of carob (Ceratoniasiliqua L.) as influenced by fruit ripening. Industrial Crops and Products 60: 298-303.

25. Mphahlele RR, Stander MA, Fawole OA, Opara UL (2014) Effect of fruit maturity and growing location on the postharvest contents of flavonoids, phenolic acids, vitamin $\mathrm{C}$ and antioxidant activity of pomegranate juice (cv. Wonderful). Scientia Horticulturae 179: 36-45.

26. Food and Nutrition Board (2004) Panel on Dietary Antioxidants and Related Compounds, Subcommittees on Upper Reference Levels of Nutrients and Interpretation and Uses of Dietary Reference Intakes, and the Standing Committee on the Scientific Evaluation of Dietary Reference Intakes. Dietary Reference Intakes for Vitamin C, Vitamin E, Selenium, and Carotenoids. National Academy Press: Washington.

27. Underhill SJR, Critchley C (1992) The physiology and anatomy of lychee (Litchi chinensisSonn.) pericarp during fruit development. Journal of Horticultural Science 67: 437-444.

28. McGuire RG (1992) Reporting of objective color measurements. Hort Science 17: 1254-1255.

\begin{tabular}{|l|}
\hline \multicolumn{1}{|c|}{ Your next submission with Juniper Publishers } \\
will reach you the below assets \\
- Quality Editorial service \\
- Swift Peer Review \\
- Reprints availability \\
- E-prints Service \\
- Manuscript Podcast for convenient understanding \\
- Global attainment for your research \\
- Manuscript accessibility in different formats \\
( Pdf, E-pub, Full Text, Audio) \\
- Unceasing customer service \\
Track the below URL for one-step submission \\
https://juniperpublishers.com/online-submission.php \\
\hline
\end{tabular}

